\title{
Entrepreneurship Education and Antecedents of Entrepreneurial Intention among University Students in South western Nigeria
}

\author{
Ojo Afolabi Ayotunde \\ Department of Business Administration and Marketing, Redeemer's University
}

\begin{abstract}
Faced with challenge of high unemployment rate, there is need for a drastic step to prepare the youths who account for majority of the unemployed figure for entrepreneurial activities rather than just preparing them to hunt for jobs after their study. While it is compulsory for higher institutions in Nigeria to take entrepreneurship courses, there is little evidence on its impact on students' entrepreneurial intentions. The purpose of this paper is to add to the literature on entrepreneurial intention using the theory of planned behaviour to examine the intentions of university students in southwestern Nigeria. In this paper, Entrepreneurial Intention Questionnaire (EIQ) was used to measure entrepreneurial intentions using a sample of 127 final year students from one of the foremost private universities in southwestern Nigeria; Redeemer's University, Ede, Osun State, Nigeria. Ordinary Least Square (OLS) regression was used to determine the effect of the explanatory variable on the dependent variables. The result shows a positive but weak relationship between entrepreneurship education and antecedents of entrepreneurial intention. The study concludes that having entrepreneurship education may not totally translate into job creation hence, it was recommended that there is need for government and other stakeholders to consider other factors that influence entrepreneurship intention.
\end{abstract}

Keywords: Entrepreneurship, Entrepreneurship Education, Entrepreneurship Intention

\section{INTRODUCTION}

$\mathrm{I}_{\mathrm{s}}^{\mathrm{s}}$ is no longer news that the rate of unemployment in Nigeria is on the increase. Blessed with an estimated population of 173 million people (World Bank, 2015), which ordinarily should be a blessing to economic development of Nigeria has not been able to live up to expectation. Among the many challenges facing the country is that of youth unemployment, majority being between the ages of 15 to 24 and 25 to 34 years with a rate of $17.8 \%$ and $10.8 \%$ respectively (Barungi, Odhiambo, Asogwa and Zerihun, 2016). According to Trading Economics (2021), the current figure is put at $33.3 \%$ in the fourth quarter as against $27.10 \%$ which was recorded in the second quarter of 2020. This is against what was recorded in 1963 when unemployment was seen as insignificant with a rate below 2\% (Dionco-Adetayo, 2014). It was also estimated that $11.7 \%$ of those with postsecondary education are unemployed (Barungi et al., 2016). Every year, both public and private academic institutions produce thousands of graduates, many of whom end up not securing a job. The era of securing an automatic white-collar job after graduation from college or university because the job offers are diminishing and the few available are highly competitive. A candidate with a high grade is not guaranteed a place as it used to be, it is that bad. It is time for graduates to look inward and start thinking of what they can do to be selfemployed. If several people who do not rely on their certificate or have formal education are creating jobs and are employers of graduates today, nothing stops graduates from doing the same if not more (Alade, 2019).

Nigeria, despite being blessed with enormous natural resources and being the largest oil exporter in Africa, one would have imagined unemployment to be the least of her challenges, however the rate of unemployment has been on the increase as shown in Figure 1 despite the effort by the various governments and government ministries.

For example, in 2010 the then President, Goodluck Jonathan, introduced the "Youth Enterprise With Innovation In Nigeria" (YouWin) programme (African Economic Outlook, 2012) in order to promote and encourage youth business ideas while the ministry of Youth Development launched The Nigerian Youth Entrepreneurship Development Programme aimed to equip 10,000 youths between the ages of 18 and 35 years with entrepreneurial skills (African Economic Outlook, 2012). The latest intervention to reduce unemployment among the youth is the effort by the current administration led by President Muhammadu Buhari through the introduction of a social empowerment programme tagged $\mathrm{N}$-power which intend to employ 500,000 unemployed graduates (N-Power, 2017). 


\section{Figure 1: Nigeria Unemployment Rate}

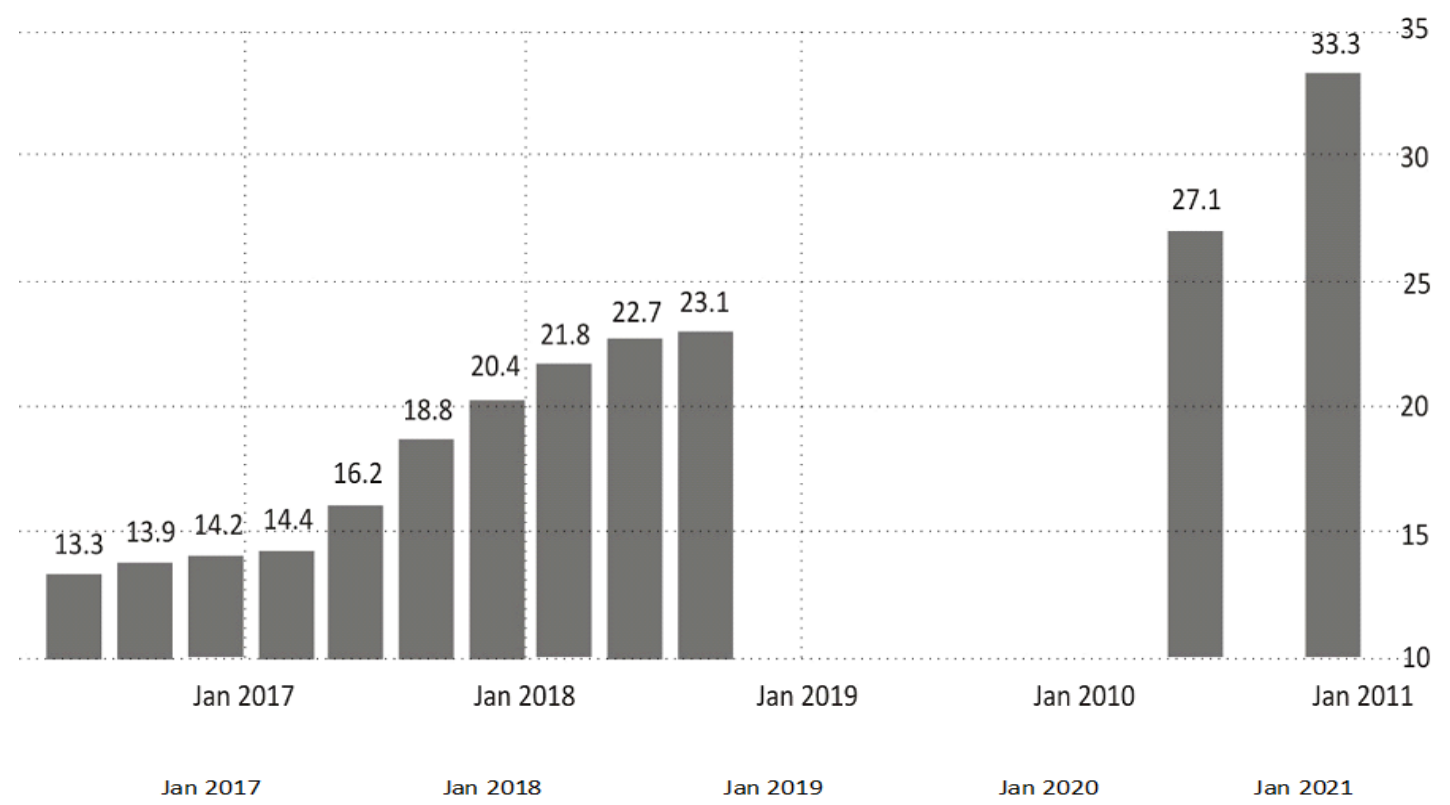

Despite all these efforts, the pace of job creation by both public and private sectors has been inadequate, for example, the ratio of the 500,000 recently employed under the social empowerment scheme is nothing when compared with the population of the unemployed in the country. This has led to frustration among underemployed youths (World Bank, 2015).

There are various vocations and entrepreneurial activities which can be transformed into a business if well followed through. According to Fayolle, and Gailly (2015), doing some courses or a career in entrepreneurship provides an avenue for individuals to be independent financially and also contribute to the economy through job creation, innovation and economic growth. Having recognised this importance, that is reducing the problem of youth employment, the Nigerian government make it compulsory to include entrepreneurship education into the school's curriculum in 2006 through the Nigerian University Commission (Simeon-Fayomi, 2015). However, despite entrenching entrepreneurship study as part of the curriculum of universities in Nigeria, only few actually end up practicing what they've learnt, that is starting a business of their own after graduation. This is in line with the findings of Lucky \& Minai, (2011). One would have expected majority of the students would have gained enough knowledge and experience to start their own business but many still rely on the labour market to look for jobs which are limited. It is on this premise that this study is based.

Many researchers have studied the intentions of students becoming entrepreneurs but the evidence from Nigeria is very lean. This study will fill the gap and it would be of great value to entrepreneurial process.

Objectives
The purpose of this study is to evaluate the effect of entrepreneurship education on antecedents of entrepreneurial intention of university students in southwestern Nigeria using the Theory of Planned Behaviour (Ajzen, 1991). The specific objectives of the study include:

i. To determine impact of entrepreneurship education on students' attitudes towards entrepreneurship.

ii. To evaluate the effect of entrepreneurship education on subjective norms among university students

iii. To investigate the influence of entrepreneurship education on perceived behavioural control of university students.

Hypotheses

Emanating from the objectives are the following hypotheses which are going to be tested:

Hol: There is no significant impact of entrepreneurship education on students' attitudes towards entrepreneurship.

Ho2: There is no significant impact of entrepreneurship education on subjective norms among university students.

Ho3: There is no significant impact of entrepreneurship education on perceived behavioural control of students.

\section{LITERATURE REVIEW}

\section{Entrepreneurship}

Entrepreneurship holds a particularly important position in the development of any economy, be it developing or developed. Countries are beginning to see the importance of 
entrepreneurship as a means of boosting economic development through job creation. Entrepreneurship has been practiced as far back as human existence (Falcone and Osborne, 2005). Even though there is no universally acceptable definition, effort have been made by various researchers to explain this concept along their line of disciplines. For example, classic models of economic behaviour and innovation is used by the economists, characteristics of entrepreneurs by the behaviourist while the resourcefulness and organising capabilities of entrepreneurs were used by the people in management (Agunbiade et al, 2015).

It is no longer news that youth unemployment is on the increase in Nigeria (Agunbiade, Afolabi and Adeleke, 2015). Sondari (2013) observed that there is a great tendency of having younger generation ages of 18 to 25 embrace entrepreneurship. Hence, one of the major ways of solving the problem of unemployment of young people is through encouragement of entrepreneurship-oriented activities and training (Gunu and Tsado, 2017; Wassim, 2016; Thavaraj, 2012). It is a means by which millions of people gain access to engage in profitable economic activities (Kuratko, 2005).

In other to boost entrepreneurial intention, entrepreneurship education and venture creation programs have been introduced to the curriculum in various higher institutions of learning at undergraduate and postgraduate levels (Kuratko, 2015), likewise the establishment of various vocational training centres to augment the knowledge acquired from formal educational establishments. This is as a result of the potential contributions of entrepreneurship graduates to the development of their countries (Hattab, 2014).

\section{Entrepreneurship Education}

Entrepreneurship Education (EE) is seen as any educational programme or process of education for entrepreneurial attitudes and skills, which involves developing certain personal qualities (Fayolle, Gailly, \& Lassas-Clerc, 2006). Thus, EE seeks to empower students with the right skills, knowledge and motivation to encourage entrepreneurial success. Researchers found out that EE has significant impact on entrepreneurship intention. Noel (1998) observed that Students with majors in entrepreneurship expressed higher intention in starting their own business. Also, Dyer (1994), and Fayolle et al (2006) supported this view by stating that interest in entrepreneurship as a career is influenced by entrepreneurship education. This may be the reason why governments in different countries especially the developing ones have introduced courses or programmes in entrepreneurship which must be passed as a prerequisite for award of degree or other certificates as the case may be. This will help to inculcate the entrepreneurial orientation into the upcoming generation in other to reduce the problem of youth unemployment and drive economic development and growth (Gunu and Tsado, 2017; Ibrahim and Lucky, 2011).
Areas of entrepreneurship education include nature of business entry, idea generation, skill-building courses in negotiation, leadership, new product development, creative thinking, and exposure to technological innovation. Others are sources of capital, traits or characteristics of entrepreneurs, and challenges that may be encounter in the business (Kuratko, 2005). He further identified three major sources of information about understanding entrepreneurial process which provided the background about entrepreneurship education including popular publications (such as academic journals, textbook and books on entrepreneurship, newsletters, Biographies or autobiographies of entrepreneurs, conference proceedings, government publications, etc) direct observation of practicing entrepreneurs, speeches and seminars of practicing entrepreneurs,

\section{Entrepreneurial Intention}

Different authors have tried to define entrepreneurial intention. It is the "self-acknowledged conviction of the individual mind in the possibility of starting up a new business with a sincere and dedicated plan to so at a certain point of time" (Thompson, 2009 cited in Ibrahim and Lucky, 2015). Bird (1988) defined entrepreneurship intention as the mind sets that direct, guide, coordinate and control the basic concept (action) of new business development, implementation and evaluation. Also, Krueger and Brazeal (1994), referred to it as student's cognitive inclination to choose and pursue an entrepreneurial career (e.g., starting a new business) after graduation. Thus, Intention is what pushes entrepreneurial activities. It is a major determinant in taking action towards creating new business venture moderated by exogenous variables such as parents, occupation, etc (DioncoAdetayo, 2006). However, in this study, the researcher adopted the definition given by Krueger and Brazeal. Many studies have been carried out on why people either choose to be self-employed or start their businesses and or prefer to work for others. One major model that has helped to understand entrepreneurial intentions is the Theory of Planned Behaviour (TBD) (Ajzen, 1991). This theory is further discussed in the next section.

\section{Theory of Planned Behaviour (TPB)}

Deciding to start an enterprise should be preceded by behaviour. One of the most widely used theories in understanding entrepreneurial intentions of an individual is the Theory of Planned Behaviour (TBB), derived from social psychology, as shown in Figure 2. This theory helps in having a better understanding of the complexities of human social behaviours (Ajzen, 1991, Kautonen et al., 2013, 2015). According to Ajzen, 1991, the emphasis of this model is on three major components which influence on intention. They are (a) attitude toward the behaviour (ATB), (b) subjective norms ( $\mathrm{SN}$ ), and (c) perceived behavioural control (PBC). Attitude is the extent to which an individual has either a favourable or unfavourable evaluation about doing the target behaviour (for example being an entrepreneur); subjective norms is the social pressures towards performing or refraining 
from a particular behaviour (e.g., becoming an entrepreneur) while perceived behaviour control is the perceived difficulty or how easy it is to perform the behaviour (e.g., becoming an entrepreneur).

TPB have been used to predict university students' intention to start a business enterprise. Most researchers often use convenience samples of students in their first year or final year at undergraduate level and in some cases at postgraduate level in various countries as evidenced in the various research carried out. For example, first year students of Faculty of Commerce and Management Studies in India (Bhandari, 2006), first year undergraduate students in Norway (Kolvereid, 1996), students from Spanish university (Rueda, Moriano, and Linan, 2015), final-year business students in Saudi Arabia (Wassim, 2016), master's programs students in France (Fayolle and Gailly, 2015). Also, studies have also been carried out using data from multiple countries such are students from Russia and Ukraine (Iakovleva and Solesvik, 2014), students from 17 European countries (Merle, Marianne, Urve and Aino, 2013), Spain and Taiwan (Linan and Chen, 2009). These studies give credence to the extent to which the TPB has been used to predict entrepreneurial intention of university students. Despite its applicability in different contexts, its usage in developing countries especially in Africa has not been well established. Thus, in this study, attention will be on the application of the theory in studying the intent of Nigeria university students toward establishing a business.

Figure 2: Relationship between entrepreneurial education and antecedents of entrepreneurial intentions

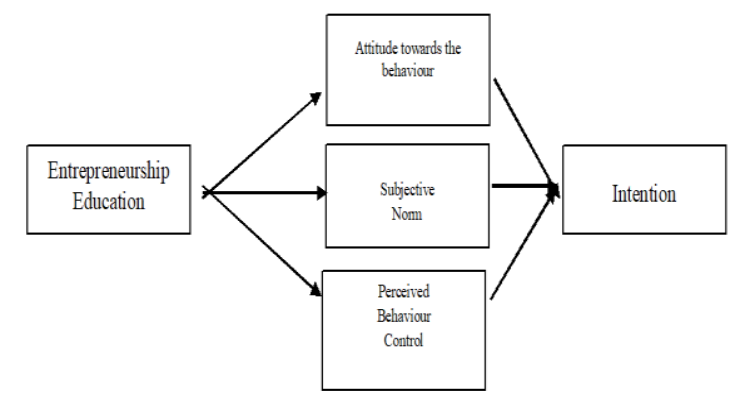

Source: Adapted from (Ajzen, 1991), Ajzen's Theory of Planned Behaviour

Source: Adapted from (Ajzen, 1991), Ajzen's Theory of Planned Behaviour

\section{METHODOLOGY}

Survey method was used to examine the intentions of students in their final year in Redeemer's University, Ede, Osun State, Nigeria in two departments in the College of Management and Social Sciences of the University. The two departments were Financial Studies made up of students in two majors: Accounting, and Banking and Finance, and Economics and Business Studies department with Economics, and Business Administration majors. The final year students were found to be appropriate because these set of respondents have taken courses in entrepreneurship in the course of the three-year or four-year programme as the case may be and are faced more with the challenges of career choice (Wassim, 2016; Krueger,
Reilly, and Carsrud, 2000), have higher propensity of becoming entrepreneurs and thus may be able to answer the questions more consciously (Linan and Chen, 2009).

The Hypotheses (Ho1, Ho2, and Ho3) describe the relationship between entrepreneurship education and antecedents of intentions of students. Data about these variables were collected using the entrepreneurial intentions questionnaire developed by Kolvered (1996) with a few modifications. The questionnaire used in the study consisted of two major sections. The first section is made up of demographic characteristics of respondents, e.g., age, gender, field of study, parent or relatives owning a business, entrepreneurship and social experiences, and entrepreneurship training, while the second section includes the core elements from the entrepreneurship intention model.

The study used simple regression analysis, Ordinary Least Square (OLS) to determine the effect of the explanatory variable on the dependent variables. The model specification is as follows:

$$
\begin{array}{ll}
\text { i. } & \mathrm{ATB}=\alpha+\mathrm{EE} \beta+\mu \\
\text { ii. } & \mathrm{SN}=\alpha+\mathrm{EE} \beta+\mu \\
\text { iii. } & \mathrm{PBC}=\alpha+\mathrm{EE} \beta+\mu
\end{array}
$$

Where:

$\mathrm{EE}=$ Entrepreneurship Education

ATB $=$ Attitude towards Behaviour

$\mathrm{PBC}=$ Perceived Behavioral Control

$\alpha=$ intercept or constant

$\beta=$ Coefficient of determination

$\mu=$ error term

\section{Data Analysis}

Descriptive statistics were used and Table I includes the relevant characteristics of the sample. The study involved 127 sample size with the following demographic characteristics; $44.9 \%$ were male while $55.1 \%$ were female. In terms of age, majority are between the ages of 20 to 25 years $(55.1 \%)$, both Accounting and Economics majors had 29.9\% each, 22.8\% were Business Administration, and $17.3 \%$ were Banking and Finance majors.

In terms parent or relatives owning a business, $70.9 \%$ (Yes) and $29.1 \%$ (No), and $71.7 \%$ (Yes) and $26.8 \%$ (No) respectively. $60.6 \%$ have business experience in a firm while $39.4 \%$ does not have, also $77.2 \%$ has entrepreneurship training while $22.8 \%$ does not. All these were measured with a single question with a response scale of Yes/No. The variables related to entrepreneurship intention and TPB antecedents were measured using a seven-point Likert scale with extremes "Strongly disagree" and Strongly agree", and "Total disapproval" and "Total approval" as the case may be. 
Table I: Sample characteristics and frequency distribution

\begin{tabular}{|c|c|c|c|}
\hline Variable & & Frequency & Valid per cent \\
\hline \multirow[t]{2}{*}{ Sex } & Male & 57 & 44.9 \\
\hline & Female & 70 & 55.1 \\
\hline \multirow[t]{3}{*}{ Age } & $<20$ & 47 & 37.0 \\
\hline & $21-25$ & 71 & 55.9 \\
\hline & $26 \&$ above & 9 & 7.1 \\
\hline \multirow[t]{4}{*}{ Field of Study } & Accounting & 38 & 29.9 \\
\hline & $\begin{array}{c}\text { Banking \& } \\
\text { Finance }\end{array}$ & 22 & 17.3 \\
\hline & Economics & 38 & 29.9 \\
\hline & Bus. Admin & 29 & 22.8 \\
\hline \multirow[t]{2}{*}{ Parent Owner } & Yes & 90 & 70.9 \\
\hline & No & 37 & 29.1 \\
\hline \multirow[t]{2}{*}{ Relatives } & Yes & 91 & 71.7 \\
\hline & No & 36 & 28.3 \\
\hline \multirow[t]{2}{*}{$\begin{array}{c}\text { Business } \\
\text { Experience }\end{array}$} & Yes & 77 & 60.6 \\
\hline & No & 50 & 39.4 \\
\hline \multirow[t]{2}{*}{$\begin{array}{c}\text { Entre. } \\
\text { Training }\end{array}$} & Yes & 98 & 77.2 \\
\hline & No & 29 & 22.8 \\
\hline
\end{tabular}

Note: $\mathrm{n}=127$

Source: Author's analysis from SPSS 23.0

\section{IV.RESULTS AND DISCUSSION}

The hypotheses were tested using regression analysis. Regression analysis is appropriate to predict the value of a variable based on another variable.

Hypothesis 1 stated that there is no significant impact of entrepreneurship education on students' attitudes towards entrepreneurship. The result shows that the coefficient of determination $\mathrm{R}^{2}$ which is the explanatory power of the model is .031. This implies that Entrepreneurship Education can only explain $3.1 \%$ variation in Attitude towards behaviour; the remaining $96.9 \%$ is explained by other variables that are not considered in the model.

Although the explanatory power of Entrepreneurship Education on attitude towards planned behaviour is not so strong, there is however a positive relationship that exist between the two variables. The Correlation coefficient ' $r$ ' is .177 , indicating that there is a statistically significant correlation between the two variables. This implies that as there is an increase in Entrepreneurship Education, there will likely be an increase in attitude towards planned behaviour. Regression coefficient $\beta$ is positive and a unit change in EE will cause an increase in Attitude towards Planned Behaviour by 1.05 . The $t$ value is 2.01 , this further implies that EE has significant positive effect on Entrepreneurial Intention.

We will however reject the hypothesis $\mathrm{H} 1$ since our p-value which is 0.046 is less than 0.05 and the model if applied will statistically significantly explain attitude towards planned behaviour.

\begin{tabular}{|c|c|c|c|c|}
\hline \multicolumn{5}{|c|}{ Table II: Model Summary } \\
\hline $\begin{array}{c}\text { Mod } \\
\text { el }\end{array}$ & $\mathrm{R}$ & $\begin{array}{c}\mathrm{R} \\
\text { Square }\end{array}$ & $\begin{array}{c}\text { Adjusted R } \\
\text { Square }\end{array}$ & $\begin{array}{c}\text { Std. Error of } \\
\text { the Estimate }\end{array}$ \\
\hline 1 & $.177^{\mathrm{a}}$ & .031 & .024 & 9.40121 \\
\hline \multicolumn{5}{|c|}{ Predictors: (Constant), Entrepreneurship Education } \\
Source: Output from SPSS 23.0 \\
\hline
\end{tabular}

\begin{tabular}{|c|c|c|c|c|c|c|}
\hline \multicolumn{7}{|c|}{ Table III: ANOVA $^{\mathrm{a}}$} \\
\hline \multicolumn{2}{|c|}{ Model } & $\begin{array}{c}\text { Sum of } \\
\text { Squares }\end{array}$ & Df & $\begin{array}{c}\text { Mean } \\
\text { Square }\end{array}$ & F & Sig. \\
\hline \multirow{4}{*}{1} & $\begin{array}{c}\text { Regress } \\
\text { ion }\end{array}$ & 358.683 & 1 & 358.683 & 4.058 & $.046^{\mathrm{b}}$ \\
\cline { 2 - 7 } & $\begin{array}{c}\text { Residua } \\
1\end{array}$ & $\begin{array}{c}11047.83 \\
6\end{array}$ & 125 & 88.383 & & \\
\cline { 2 - 7 } & Total & $\begin{array}{c}11406.52 \\
0\end{array}$ & 126 & & & \\
\hline \multicolumn{7}{|c|}{ a. Dependent Variable: Attitude Towards Behaviour } \\
\hline \multicolumn{7}{|c|}{ b. Predictors: (Constant), Entrepreneurship Education } \\
\hline
\end{tabular}

\begin{tabular}{|c|c|c|c|c|c|c|}
\hline \multicolumn{7}{|c|}{ Table IV: Coefficients ${ }^{\mathrm{a}}$} \\
\hline & \multirow[t]{2}{*}{ Model } & \multicolumn{2}{|c|}{$\begin{array}{l}\text { Unstandardized } \\
\text { Coefficients }\end{array}$} & \multirow{2}{*}{$\begin{array}{c}\begin{array}{c}\text { Standar } \\
\text { dized } \\
\text { Coeffici } \\
\text { ents }\end{array} \\
\text { Beta }\end{array}$} & \multirow[t]{2}{*}{$\mathrm{T}$} & \multirow[t]{2}{*}{ Sig. } \\
\hline & & B & $\begin{array}{l}\text { Std. } \\
\text { Error }\end{array}$ & & & \\
\hline \multirow[b]{2}{*}{1} & (Constant) & 5.705 & 9.416 & & .606 & .546 \\
\hline & $\begin{array}{l}\text { Entrepreneurshi } \\
\text { p Education }\end{array}$ & 1.058 & .525 & .177 & $\begin{array}{c}2.01 \\
5\end{array}$ & .046 \\
\hline & $\begin{array}{l}\text { a. } \quad \text { Dependent } \\
\text { So }\end{array}$ & $\begin{array}{l}\text { iable: } \\
\text { e: Out }\end{array}$ & $\begin{array}{l}\text { ude } \mathrm{T} \\
\text { rom } \mathrm{S}\end{array}$ & $\begin{array}{l}\text { rds Beh } \\
23.0\end{array}$ & & \\
\hline
\end{tabular}

Hypothesis 2 stated that there is no significant impact of entrepreneurship education on subjective norms among university students. The result is presented in Table V, VI, and VII.

From Table V, the co-efficient of determination $\mathrm{R}^{2}$ is 0.003 which indicates EE can explain only $0.3 \%$ variation in $\mathrm{SN}$, meaning that $99.7 \%$ is explained by other variables that are not considered in the model. There is however a positive relationship between the two variables even though the explanatory power of EE on $\mathrm{SN}$ is low. The correlation coefficient ' $r$ ' is 0.56 indicating that there is a statistically significant correlation between the two variables. Thus, as there is increase in EE, there will be an increase in $\mathrm{SN}$ of the students. Regression coefficient $\beta$ is positive and a unit 
change in EE will cause an increase in SN by 0.195 . the $t$ value is 0.629 , this further implies that $\mathrm{EE}$ has a positive effect on Entrepreneurial Intention. Hence $\mathrm{H} 2$ is accepted since the p-value which is 0.530 is greater than 0.05 .

\begin{tabular}{|c|c|c|c|c|}
\hline \multicolumn{5}{|c|}{ Table V: Model Summary } \\
\hline $\begin{array}{c}\text { Mode } \\
1\end{array}$ & $\mathrm{R}$ & R Square & $\begin{array}{c}\text { Adjusted R } \\
\text { Square }\end{array}$ & $\begin{array}{c}\text { Std. Error of } \\
\text { the Estimate }\end{array}$ \\
\hline 1 & $.056^{\mathrm{a}}$ & .003 & -.005 & 5.54823 \\
\hline a. & Predictors: (Constant), Entrepreneurship Education \\
Source: Output from SPSS 23.0
\end{tabular}

\begin{tabular}{|c|c|c|c|c|c|c|}
\hline \multicolumn{7}{|c|}{ Table VI: ANOVA $^{\mathrm{a}}$} \\
\hline \multirow{2}{*}{ Model } & $\begin{array}{c}\text { Sum of } \\
\text { Squares }\end{array}$ & Df & $\begin{array}{c}\text { Mean } \\
\text { Square }\end{array}$ & F & Sig. \\
\hline \multirow{4}{*}{1} & $\begin{array}{c}\text { Regres } \\
\text { sion }\end{array}$ & 12.190 & 1 & 12.190 & .396 & $.530^{\mathrm{b}}$ \\
\cline { 2 - 7 } & $\begin{array}{c}\text { Residu } \\
\text { al }\end{array}$ & $\begin{array}{c}3847.85 \\
7\end{array}$ & 125 & 30.783 & & \\
\cline { 2 - 7 } & Total & $\begin{array}{c}3860.04 \\
7\end{array}$ & 126 & & & \\
\hline \multicolumn{7}{|c|}{ a. Dependent Variable: Subjective Norm } \\
\hline \multicolumn{7}{|c|}{ b. Predictors: (Constant), Entrepreneurship Education } \\
\hline
\end{tabular}

Source: Output from SPSS 23.0

\begin{tabular}{|c|c|c|c|c|c|c|}
\hline \multicolumn{7}{|c|}{ Table VII: Coefficients $^{\mathrm{a}}$} \\
\hline \multirow{2}{*}{ Model } & \multicolumn{2}{|c|}{$\begin{array}{c}\text { Unstandardized } \\
\text { Coefficients }\end{array}$} & $\begin{array}{c}\text { Standar } \\
\text { dized } \\
\text { Coeffici } \\
\text { ents }\end{array}$ & \multirow{2}{*}{ T } & Sig. \\
\cline { 3 - 7 } & B & $\begin{array}{c}\text { Std. } \\
\text { Error }\end{array}$ & Beta & & \\
\hline \multirow{2}{*}{1} & (Constant) & 10.430 & 5.557 & & $\begin{array}{c}1.87 \\
7\end{array}$ & .063 \\
\cline { 2 - 7 } & $\begin{array}{c}\text { Entrepreneurshi } \\
\text { p Education }\end{array}$ & .195 & .310 & .056 & .629 & .530 \\
\hline \multicolumn{7}{|c|}{ a. Dependent Variable: Subjective Norm } \\
\hline
\end{tabular}

Source: Output from SPSS 23.0

Hypothesis 3 stated that there is no significant impact of entrepreneurship education on perceived behavioural control of university students. The result is presented in Table VIII, IX, and X.

Looking at the results in Tables VIII, IX and X, the results show that the coefficient of determination $\mathrm{R}^{2}$ is 0.003 which also indicate that EE can explain only $0.3 \%$ variation in PBC of the students. This implies that there are other factors that influence PBC other than EE, these factors account for $99.7 \%$. There is however a positive relationship between EE and PBC although the explanatory power of EE is low. The correlation coefficient ' $r$ ' is 0.50 indicating that there is a statistically correlation between the two variables. This implies that as there is an increase in EE, there will be an increase in the PBC of the students. Regression coefficient $\beta$ is positive and a unit change in EE will cause an increase in PBC of the students by 0.287 . The $t$ value is 0.565 , this implies that $E E$ has significant positive effect on Entrepreneurial Intention. We therefore accept Hypothesis 3 since the p-value of 0.573 is greater than 0.05 .

\begin{tabular}{|c|c|c|c|c|}
\hline \multicolumn{5}{|c|}{ Table VIII: Model Summary } \\
\hline $\begin{array}{c}\text { Mode } \\
1\end{array}$ & $\mathrm{R}$ & R Square & $\begin{array}{c}\text { Adjusted R } \\
\text { Square }\end{array}$ & $\begin{array}{c}\text { Std. Error of } \\
\text { the Estimate }\end{array}$ \\
\hline 1 & $.050^{\mathrm{a}}$ & .003 & -.005 & 9.09904 \\
\hline \multicolumn{5}{|c|}{ a. Predictors: (Constant), Entrepreneurship Education } \\
\hline
\end{tabular}

Source: Output from SPSS 23.0

\begin{tabular}{|c|c|c|c|c|c|c|}
\hline \multicolumn{7}{|c|}{ Table IX: ANOVA ${ }^{\mathrm{a}}$} \\
\hline \multicolumn{2}{|c|}{ Model } & $\begin{array}{c}\text { Sum of } \\
\text { Squares }\end{array}$ & Df & $\begin{array}{c}\text { Mean } \\
\text { Square }\end{array}$ & F & Sig. \\
\hline \multirow{2}{*}{1} & $\begin{array}{c}\text { Regres } \\
\text { sion }\end{array}$ & 26.431 & 1 & 26.431 & .319 & $.573^{\mathrm{b}}$ \\
\cline { 2 - 7 } & $\begin{array}{c}\text { Residu } \\
\text { al }\end{array}$ & 10349.065 & 125 & 82.793 & & \\
\cline { 2 - 7 } & Total & 10375.496 & 126 & & & \\
\hline \multicolumn{7}{|c|}{ a. Dependent Variable: Perceived Behavourial Control } \\
\hline \multicolumn{7}{|c|}{ b. Predictors: (Constant), Entrepreneurship Education } \\
\hline
\end{tabular}

Source: Output from SPSS 23.0

\begin{tabular}{|c|c|c|c|c|c|c|}
\hline \multicolumn{7}{|c|}{ Table X: Coefficients ${ }^{\mathrm{a}}$} \\
\hline & \multirow[t]{2}{*}{ Model } & \multicolumn{2}{|c|}{$\begin{array}{c}\text { Unstandardized } \\
\text { Coefficients }\end{array}$} & \multirow{2}{*}{$\begin{array}{c}\begin{array}{c}\text { Standard } \\
\text { ized } \\
\text { Coeffici } \\
\text { ents }\end{array} \\
\text { Beta }\end{array}$} & \multirow[t]{2}{*}{$\mathrm{T}$} & \multirow[t]{2}{*}{ Sig. } \\
\hline & & B & $\begin{array}{c}\text { Std. } \\
\text { Error }\end{array}$ & & & \\
\hline \multirow{2}{*}{1} & (Constant) & $\begin{array}{c}19.93 \\
4\end{array}$ & 9.113 & & $\begin{array}{l}2.1 \\
87\end{array}$ & .031 \\
\hline & $\begin{array}{l}\text { Entrepreneurs } \\
\text { hip Education }\end{array}$ & .287 & .508 & .050 & $\begin{array}{c}.56 \\
5 \\
\end{array}$ & .573 \\
\hline
\end{tabular}

Source: Output from SPSS 23.0

The research shows that the TBD is widely used and can be used to predict intentions relating to entrepreneurship. The aim of the study was to investigate the entrepreneurial intentions of university students in southwestern Nigeria. The results provide strong evidence that the antecedents of entrepreneurial intention contribute significantly to the explanation of intentions. The findings are in line with previous studies in terms of significant relationship between antecedents of entrepreneurial education and entrepreneurial intention and thus further support the application of Ajzen's theory of planned behaviour in order to predict and understand an individual entrepreneurial behaviour.

The study has some limitations. Firstly, the study is based on private university students only. This may make it difficult applying same in the conventional universities. It is recommended that future study should make use of bigger dataset which should include students from federal and stateowned universities. Also, a comparative study could be carried out e.g., private and conventional universities, universities and polytechnics, furthermore the students' intention could be studied before and after entrepreneurship education must have been taken. 


\section{CONCLUSION}

The study appraised the effect of entrepreneurship education on antecedents of entrepreneurial intention using the theory of planned behaviour. The results from the study established a link between $\mathrm{EE}$ and antecedents of entrepreneurship intention. However, even though there is a positive relationship between $\mathrm{EE}$ and the three variables, the explanatory power of $\mathrm{EE}$ is low, meaning $\mathrm{EE}$ may not be enough to influence the behaviour of the students towards establishing a business even though it could develop entrepreneurship competence among them. Therefore, attention should be given to other factors likely to influence intention such as conducive business environment, easy access to finance, availability of infrastructural facilities, etc.

\section{RECOMMENDATIONS}

The study recommends the following:

1. Effort should be made to give attention to other factors such as access to finance, adequate infrastructural facilities, etc., likely to trigger entrepreneurial intention aside EE among university students by the Nigerian government.

2. Universities should focus more on improved entrepreneurial curriculum contents in order to further propel students' interest towards entrepreneurship.

\section{REFERENCES}

[1] Alade, A. (2019, July 12). Degree Grade: The Cause for Unemployment and Backwardness in Africa. Daily Trust. https://dailytrust.com/degree-grade-the-cause-for-unemploymentand-backwardness-in-africa

[2] Agunbiade, O.M., Afolabi, F.J., \&Adeleke, B. (2015). Influence of Family Background on Entrepreneurship Perception and Career Intentions of Secondary School Adolescents in Nigerian City. Ife Journal of Entrepreneurship and Business Management, 1(1), 148-161

[3] Ajzen I. (1991). The Theory of Planned Behaviour. Organizational Behaviour and Human Decision Processes, 50 (2), 179-221

[4] Barungi, B., Odhiambo, O., Asogwa, R., \& Zerihun, A. (2016). African Economic Outlook: Nigeria

[5] Basu, A. \& Virick, M.(n.d.) Assessing Entrepreneurial Intentions Amongst Students: a comparative study.

[6] Bhandari N. C. (2006). Intention for entrepreneurship among students in India. The Journal of Entrepreneurship, 15 (2).

[7] Dionco-Adetayo, E. (2006). Factors influencing attitude of youth towards entrepreneurship. International Journal of Adolescence and youth 13(1/2), 127-145

[8] Dionco-Adetayo, E. (2014). Entrepreneurship education: a panacea to graduate unemployment? An inaugural lecture delivered at Oduduwa Hall, Obafemi Awolowo University, Ile-Ife, Nigeria on Tuesday $11^{\text {th }}$ November 2014.
[9] Falcone \& Osborne, S. (2005). Entrepreneurship: a diverse concept in a diverse world.

[10] Fayolle, A. \& Gailly, B. (2015). The impact of entrepreneurship education on entrepreneurial attitudes and intention: hysteresis and persistence. Journal of Small Business Management, 53(1), 75-93

[11] Fayolle, A., Gailly, B. \& Lassas-Clerc, N. (2006). Assessing the impact of entrepreneurship education programmes: a new methodology. Journal of European Industrial Training, 30(9), 701 $-720$

[12] Gunu, U. \& Tsado, E. (2017). Do Nigerian undergraduate students have what it takes to be successful entrepreneurs? An enquiry into the entrepreneurial capacity of Nigerian undergraduates. Asia Pacific Journal of Education, Arts and Sciences. 4(1), 10-19

[13] Hattab, H. W. (2014). Impact of Entrepreneurship Education on Entrepreneurial Intentions of University Students in Egypt. The Journal of Entrepreneurship, 23(1), 1-18.

[14] Hisrisch, R.D., Peters, M. P., Shepherd, D. A. \& Mombourquette, P. S. (2006). Entrepreneurship. Toronto: McGraw-Hill

[15] Iakovleva, T. \& Solesvik, M.Z. (2014). Entrepreneurial intentions in post-soviet economies. International Journal of Entrepreneurship and Small Business, 21(1), 79-100.

[16] Kolveried (1996). Prediction of employement status choice intentions. Entrepreneurship Theory and Practice, 21 (1), 47-57.

[17] Krueger, N.F. \& Brazeal, D.V. (1994). Entrepreneurial potential and potential entrepreneurs. Entrepreneurship Theory and Practice, 4,91-104.

[18] Krueger, N.F., Reilly, M.D. \& Carsrud, A.L. (2000). Competing models of entrepreneurial intentions. Journal of Business Venturing, 15 (5), 411-432.

[19] Kuratko, (2005). The Emergence of Entrepreneurship Education: Development, Trends, and Challenges. Entrepreneurship Theory and Practice 577-597

[20] Linan, F. \& Chen, Y.W. (2009). Development and cross-cultural application of a specific instrument to measure entrepreneurial intentions. Entrepreneurship Theory and Practice, 33(3), 593-617.

[21] Lucky, I., \& Minai, M. S. (2011). The Entrepreneurial Mind of the Female Graduate-to-be in Northern Malaysia. Paper presented at the Proceeding at the World Business, Economics and Finance Conference.

[22] Merle K., Marianne K., Urve V., \&Aino K. (2013). Entrepreneurship education at university level and students' entrepreneurial intentions. Contemporary Issues in Business, Management and Education

[23] N-Power (2016). http://www.npower.gov.ng

[24] Rueda, Moriano, \& Linan (2015). Validating a theory of planned behaviour questionnaire to measure entrepreneurial intention, in Fayolle, A., Kyro, P. And Linan, F. (Eds). Developing, Shaping and Growing Entrepreneurship. Edward Elgar Publishing Limited, Cheltenham, 60-78

[25] Thavaraj, H.S. (2012). Entrepreneurship among students: a two group discriminant model. International Journal of Business Management \& Research, 2(4), 53-58.

[26] Trading Economics (2021). Nigeria Unemployment rate. https://tradingeconomics.com/nigeria/unemployment-rate

[27] Wassim J. A. (2016). Predicting entrepreneurial intentions of final year Saudi university business students by applying the theory of planned behaviour. Journal of Small Business and Enterprise Development, 23 (4), 1142 - 1164

[28] World Bank (2015). Nigeria: country at a glance. Retrieved $25^{\text {th }}$ January 2016 from http://www.worldbank.org/en/country/nigeria/overview 